\title{
Leadership Tasks Associated with the Use of Coercive Means by Professional Disaster Management Bodies
}

\author{
Gotthilf SCHWEICKHARDT ${ }^{1}$
}

\begin{abstract}
Professional disaster management bodies were granted statutory authorisation on the $1^{\text {st }}$ of January 2017 to take limited coercive measures. Professional disaster management bodies are entities performing primarily state administration tasks, and secondly law enforcement tasks. Fire brigades and from the mid-1990s, professional disaster management bodies have been and are involved in the road inspection of dangerous goods in addition to other entities authorised to inspect under the Act on traffic. The use of coercive means requires special training, to which the obligation of leaders (commanders) correlates: to investigate the use of coercive means.
\end{abstract}

Keywords: disaster management, coercive device, control, dangerous goods

\section{The Professional Disaster Management Body as a Law Enforcement Body}

Before discussing the topic in the title, it is necessary to clarify a few notions. The President of the "Szemere Bertalan” Hungarian Scientific Society of the History of Law Enforcement defined law enforcement as:

"The action of the State to prevent or stop acts dangerous to public order, which undoubtedly belongs to public law, within it, it forms a branch of policing, and as such, can be regarded as part of public administration and public administration law.” [1]

\section{Certain features of law enforcement}

Its basic function: to manage internal hazards threatening safety and security. Leadership and execution are hierarchically regulated, the rule of the chain of command prevails.

The notion of policing is linked to law enforcement, it is compared to it; in this case, I skip this step and try to narrow my message exclusively to law enforcement. The system

Lieutenant Colonel, Ph.D., Master of Laws, Associate Professor, National University of Public Service, Institute of Disaster Management, Department of Disaster Management Operations; e-mail: schweickhardt. gotthilf@uni-nke.hu; ORCID: 0000-0001-5609-338X 
of tasks of professional disaster management bodies incorporates the systems of tasks of the individual bodies that constitute them. Fire protection, civil protection and, last but not least, industrial safety activities differ from each other. If water management systems are also added to these activities, it is quite clear that the state administration tasks are predominant. The protection of the life and property of the citizens of Hungary, as well as the prevention of damage to the environment can be considered largely the main tasks of professional disaster management bodies. These tasks require Hungarian citizens and foreigners to enforce and comply with national, international or other regulations, determining their actions and relevant to them, that is, to be lawful. The law-abiding behaviour, the control of compliance with the prescribed authoritative decisions is an important task, and it is clearly highlighted at present by the inspection of the transportation of dangerous goods and industrial safety. After inspection, sanctioning is done in many cases. Following the failure to comply with the prescribed conduct, the person inspected tries to escape sanctioning or wants to avoid the inspection itself. Given that the transportation of dangerous goods is fundamentally governed by international conventions, therefore, during inspections, the international element is present. Persons performing fire protection tasks have never possessed any weapons, since their main task has been and still is to prevent the breakout of fire in general. However, the civil protection system of tasks, by its very nature, is related to military activities, and as such, it is natural that the right of carrying arms is present. In relation to the system of tasks of civil protection organisations, members of civil protection organisations may carry light individual weapons for self-defence or policing in case of war or military actions, governed by the Geneva Conventions. "If the civil protection (defence) personnel of the civilian population, for reasons of maintaining order or for self-defence, are equipped with light individual weapons, it is not considered an act of harm to the enemy. However, in areas where ground forces are or may be engaged, the conflicting Parties are bound to restrict these weapons to small arms, for example, pistols or revolvers, and with appropriate measures, to promote the distinction between civil protection (defence) personnel and combat personnel. Civil protection (defence) personnel, however, starting from being recognized in such capacity of theirs, are also to be provided with mercy and protection even if, in such an area, they are equipped with other light individual weapons.” [2] Organisations constituting the individual elements of the professional disaster management organisation were earlier regarded as law enforcement bodies. With regard to the fire service, more specifically, the state fire service was defined as a policing body based on Law Decree 10 of 1973 on the protection against fire and on the fire service. [3] In 1991, Section 10 of Act XX of 1991 on the responsibilities and competences of local governments and their bodies, of commissioners of the Republic, and of certain centrally subordinated bodies, omitted the part established on uniform principles. Another change occurred when Act XLIX of 1995 deleted the definition "policing body" in its entirety. By doing so, it removed the policing tasks from the responsibilities of the fire brigades. Only firefighting and rescue tasks remained at the fire brigades. Act XXXI of 1996 on the protection against fire, rescue and the fire service, on 3 May 1996, addressed the professional fire service as a law enforcement body: "Paragraph (1) of Section 30 of the above Act says the professional state fire service and the professional municipal fire service (hereinafter referred to as the professional fire service) are law enforcement bodies established on uniform principles.” 
Point g) of Section 2 of Act XXXVII of 1996 on civil protection, on 15 May 1996, defined law enforcement bodies: "Law enforcement bodies are the Police, the non-military (civilian) national security services, the penitentiary organization, the customs and finance guard, the professional civil protection body, and the professional state and municipal fire service."

Professional disaster management bodies were established on 1 January 2000. Based on the Act establishing them, professional disaster management bodies: "The National Directorate General for Disaster Management, involved in the implementation of disaster management, integrated from the national bodies of civil protection and the state fire service, their regional bodies, integrated from county headquarters, are law enforcement bodies also performing state administration tasks.” [4]

The professional disaster management body, in this context, only consisted of civil protection organisations and of the state fire service, the professional municipal fire brigades were not included in this organisation. With regard to professional disaster management bodies, only the civil protection organisation and the state fire service were named as law enforcement bodies. The professional municipal fire service continued to be regarded as a law enforcement body. Law did not permit the use of coercive means for these law enforcement bodies. Act LVII of 2006 on central state administration bodies, and on the legal status of the members of the Government and state secretaries only confirmed that the entire professional disaster management organisation does not qualify for a law enforcement body. An interesting definition is expressed by point h) of paragraph (2) of Section 2 of the before-mentioned Act that defined the national headquarters of law enforcement bodies as a central state administration body. The State Fire Service and the Parliament Fire Brigade had a national body (headquarters), the professional municipal bodies (fire brigades) did not. The notion of civil protection logically ruled out the existence of a national headquarters, since it was defined as part of the defence system. [5] Home defence responsibilities are not law enforcement tasks. Act XLIII of 2010 on central state administration bodies, and on the legal status of the members of the Government and state secretaries, in this respect, maintained this status. A progress was only made on 1 January 2012, when Act CXXVIII of 2011 on disaster management and the amendment of certain relevant acts (hereinafter referred to as Act CXXVIII of 2011) entered into force. Act CXXVIII of 2011 defined the notion of a professional disaster management body as follows: "A professional disaster management body is a law enforcement body also fulfilling state administration tasks, whose members are professional personnel, civil servants, public employees, employees and officer cadets.” [6]

The provisions of Act XLIII of 2010 were adjusted to this status [paragraphs (2) and (5) of Section 2]. Accordingly, a law enforcement body is a central public administration body, and exclusively a professional disaster management body is a law enforcement body.

\section{Use of Coercive Means at Professional Disaster Management Bodies}

Paragraphs A-D of Section 24 of Act CXXVII of 2011 entered into force on 1 January 2017. These paragraphs regulate the normal and coercive measures that may be taken or used by the personnel of the professional disaster management body performing authoritative 
inspection tasks in the field of the transportation of hazardous materials. As I have already explained before, the professional disaster management body is a law enforcement body also performing state administration. Based on this, a professional disaster management body's basic function is to enforce the stipulations described in the legislation and regulations, authorised by the State, and to inspect and supervise them. During inspection, a situation may develop that may evoke an attack against the person performing the inspection, by the inspected, or the desire to avoid the inspection. Legislation determining the tasks for law enforcement bodies provides them with the possibility to take coercive measures. "To remove hindrances when taking measures, and to ensure the efficiency of the measures taken, stipulated by law, coercive means may be used. A person under procedure may be ordered to do or not to do, or to tolerate something." [7: 8]

Before I engage more thoroughly with the analysis, it should be stated that the use of coercive means is only an option and not an obligation.

The basis for the inspection of the transportation of hazardous materials are the belowmentioned international agreements transpositioned into the Hungarian legal system:

1. European Agreement concerning the International Carriage of Dangerous Goods by Road (ADR);

2. European Agreement concerning the International Carriage of Dangerous Goods by Inland Waterways (ADN);

3. Convention Concerning International Carriage by Rail (COTIF);

4. International Air Transport Association, Dangerous Goods Regulations (IATA DGR).

The review of the conventions specified in points 1 to 3 is mandatory every 2 years, and therefore, they are amended on these occasions.

The transposition of international conventions into the Hungarian legal system is currently governed by the following legislation:

- Act CIII of 2017 amending certain acts related to the transportation of dangerous goods;

- Government Decree 178/2017 (VII. 5.) on the promulgation of Annexes A and B to the European Agreement concerning the International Carriage of Dangerous Goods by Road, and on certain aspects of its application in Hungary;

- Government Decree 177/2017 (VII. 5.) on the promulgation of the (AND) Regulation annexed to the European Agreement concerning the International Carriage of Dangerous Goods by Inland Waterways, and on certain aspects of its application in Hungary;

- Government Decree 179/2017 (VII. 5.) on the promulgation of the Appendix of its Annex C of the Minutes adopted in Vilnius on 03 June 1999 on the amendment of the Convention concerning International Carriage by Rail (COTIF), and on certain aspects of its application in Hungary;

- Government Decree 313/2014 (XII. 12.) on the disaster management authoritative inspection concerning the air carriage of dangerous goods and on the regulation of imposing fine;

- Government Decree 312/2011 (XII. 23.) on the regulation of the uniform procedure on the inspection of the carriage of dangerous goods by rail and inland waterways during the measures by the professional disaster management body and on imposing 
fine, furthermore, on the amounts of fines imposable for certain irregularities, and on the general regulation of the authoritative tasks concerning fining;

- Government Decree 1/2002 (I. 11.) on the uniform procedure concerning the inspection of the transportation of dangerous goods by road.

The use of coercive means is one of the limitations of fundamental human rights. Hence, its use, under strict legal conditions, is subject to the simultaneous presence of the criteria under which human freedom may be restricted. Freedom, free movement, among other things, are fundamental human rights. The restriction of such fundamental rights is only permitted by statutory provision for bodies and organisations authorised to do so, and only until reaching the desired goal. A professional disaster management body, to verify the existence of lawabiding behaviour, or to enforce it, authorised by law, carries out inspections in several areas of expertise, including the transportation of dangerous goods. An important element of the inspection is that it should be carried out as defined in the legislation. If a violation occurs, it should be sanctioned. In order to be able to carry out the inspection, sometimes, it may become necessary to restrict the inspected person or the shipment. This, inter alia, may mean the temporary restriction of the free movement of a person or the temporary storage of the shipment at a specified location. Occasionally, the person inspected may want to withdraw themselves from the inspection and attempt violence against an official person inspecting. In these cases, the use of force may be necessary, which is permitted for the persons of the professional disaster management bodies authorised to do so by law to take certain coercive measures. For the personnel of professional disaster management bodies inspecting the transportation of dangerous goods, Act CXXVIII of 2011 on disaster management and the amendment of certain relevant acts ensures the use of coercive measures in case of offenses and crimes related to the tasks of professional disaster management bodies. At present, our code of offenses and other legislations do not include penal law stipulations related to the transportation of dangerous goods (e.g. ADR) and that belong solely to the responsibility of professional disaster management bodies.

With regard to using coercive means, from the aspect of professional disaster management bodies, the following principles should be considered:

- lawfulness: a member of a professional disaster management body performs their duties in their competence, keeping legal regulations;

- professionalism: the use of coercive means with adequate knowledge of theoretical and practical skills, according to legal regulations and manuals, using the most suitable means and tactics, without causing injury;

- proportionality: causing the least detriment when taking measures;

- necessity: the use of coercive means in cases, when an inspection (measure) started cannot be conducted or concluded. After achieving the required goal or breaking the resistance or preventing escape, the use of coercive means should be immediately ceased.

"It is a general requirement that coercive means may only be used by persons with adequate theoretical and practical training, who have authorization for inspecting dangerous goods transported on road.” [8] 
With all this in mind, it would seem appropriate to screen persons performing such a task on special psychology tests and have them go through training of knowledge of human nature. With these latter screenings and training courses, it would be possible to avoid the use of coercive means and establish a measure-taking culture.

Along with all this, of course, maintaining the level of professional knowledge must also be ensured. For the personnel participating in ADR inspections, regular attendance at first aid courses is required.

The inspector authorised to take coercive measures must meet three simultaneous criteria:

- having participated in course(s) providing entitlement to inspect the transportation of dangerous goods, participation in periodic refresher courses;

- successful completion of a course entitling to use coercive means;

- participating in half-yearly refresher courses.

\section{Coercive means and measures}

Coercive means or measures that may be used or taken by professional disaster management bodies may only be means or measures used or taken by the Police. During inspection activities concerning the transportation of dangerous goods, the wearing of coercive means by the inspector is ordered by the director of the regional body. Coercive means are received by the inspector before starting the inspection from the person appointed, and are returned after the end of the inspection. In cases when the wearing of coercive means during an inspection is not expedient for any reason, they must be locked in the service vehicle in a place that is not visible from the outside. The law only provides limited possibilities for professional disaster management bodies. For example, there is no possibility to screen either clothing or packages. If a person under inspection is not willing to present their ID card may be detained until the arrival of the Police. Act CXXVIII of 2011, besides physical coercion, also provides the possibility to use chemical means and/or handcuffs. The provision of the affected personnel with coercive means may exclusively take place using the coercive means in service at the Police and acquisitioned by professional disaster management bodies. For self-defence the personnel are entitled to carry chemical means and a police baton. This possibility raises several questions: may a person inspecting use a police baton during their official activities, was the use of chemical means for self-defence or to facilitate the measures taken, etc., but I am not discussing them in my present study. After the use of coercive means, there is an obligation to grant first aid and/or medical assistance.

\section{Leadership Tasks}

Before discussing specific leadership tasks, it is necessary briefly to explain some of the requirements leadership that are related to our topic.

Planning means that a commander, a leader comprehends the expedient use of resources to accomplish their task, linking them to the task. The feature of purposefulness is to make and keep high quality plans. To this end, it is necessary to adequately analyse and assess 
road inspections and plan the personnel participating in them. In addition, flexibility should also be present at planning of inspections.

Continuity means that leadership must be, in all circumstances, uninterrupted. This is a very important aspect of inspections, as road transport, apart from statutory exceptions, is ongoing every day of the year and every part of the day. Therefore, the presence of the personnel possessing proper expertise and experience should be ensured, as well as the presence of the leader controlling them efficiently.

Consistency provides for the predictability. This primarily means leadership activity. Among other things, it includes requirements authorised the personnel assigned for inspections, determined by laws and regulations, as well as objective assessment of their activities.

With regard to coercive measures, many first think of the commander's investigation. However, it is only an option for a leader. Leadership tasks are differentiated by command levels. They are as follows:

- Director General of the National Directorate General for Disaster Management (NDGDM);

- Head of the regional body;

- Head of the local body (branch office);

- Heads of certain organisations.

\section{Director General of the NDGDM}

As the chief executive of the professional disaster management body, he defines the requirements of the acquisition of coercive means. His most important task is to issue an internal regulator, in which, under the law, he imposes the personal and material conditions concerning coercive means, the internal rules of investigation after the use of the coercive means and the creation of legal unity. The organisation of training courses and regular refresher courses for the affected personnel is part of their responsibilities. Of course, in close relation, they regularly order to assess and analyse the legitimacy and the professionalism of taking coercive measures. If necessary, they would take measures to restore lawfulness.

The control of the inspection activity of the transportation of dangerous goods, within the organisation, is in the responsibility of the deputy director general for authoritative affairs. Taking this into account, the national level tasks of the assessment process following the use of coercive measures are performed by them. The Director General reviews appeals against the use of coercive measures.

\section{Head of the Regional Body (County Director)}

The county director performs several tasks related to coercive measures. First, wearing coercive means falls within his competence. This task is related to the planned and extraordinary inspection tasks of county directorates and branch offices. This activity is considered an administrative, automatic activity. Behind ordering the wearing of 
coercive means, in case of professional disaster management bodies, several inspection and verification tasks appear, contrary to the Police. Ordering the wearing of coercive means for inspection is possible in several ways. In case of the county personnel, since the person ordering the wearing of coercive means for the inspectors is located in the same building, therefore, in this case, the person ordering it may verify the inspector's suitability almost every time. The range of suitability extends to the status of being non-influenced by drugs or alcohol. The eligibility to issue coercive means to an inspector is verifiable from documents and records. In case of a branch office, the director can only check this task periodically on the site and at the time of issuing. The instruction to wear coercive means is issued in advance, according to the inspection plan, and in case of a person replacing an inspector who is not inspecting for any reason, an individual decision shall be made. The director also has the task of designating a person performing the issue and reception of coercive means, and, of course, the appointment of their deputy, furthermore, taking into account the particularities of the area of the directorate and the regulation of other possible tasks related to coercive measures. The director shall regulate the rules of reporting following the use of coercive means and the activities of the central duty office in relation. The installation of duty offices of regional police and disaster management bodies in one building accelerates and facilitates the eventual measures to be taken by the Police. Cases when an inspector performs inspections outside their jurisdiction, in the area of other directorates, may not be omitted from the reporting system. Based on relevant legislation and public administration regulative means, the director shall ensure the control of status of coercive means and only means meeting the requirements shall be issued. The director's additional responsibilities are to organise refresher courses for the inspectors every six months, involving the regional Police Headquarters or the National Tax and Customs Office. The director is also responsible for the appointment of mentors and to ensure refresher courses for them as well. If the inspector is on the county staff, they may inspect the carriage of dangerous goods by air, as well; in such cases, they, as the head of the body taking measures, investigate the rules of using coercive means. (The investigation is detailed in the section discussing the head of the branch office.)

\section{Head of the Local Body (Head of the Branch Office)}

The inspection of the transportation of dangerous goods, with the exception by air, is in the competence of disaster management branch offices. Therefore, in general, the head of a branch office is responsible for taking measures in relation to the inspectors belonging to the personnel of the branch office. The head of the branch office, with the help of the industrial safety inspector and the head of the authoritative section, ensures the daily training of the inspectors on their staff, including raising the awareness of new legislation. The verification of the preparedness of the inspectors can be successfully performed by the head of the branch office with the help of the above-mentioned two officers. Before the inspection, in the framework of a briefing, the inspectors' knowledge shall be verified. At this briefing, besides professional issues, other topics concerning the inspection, including the eligibility of taking coercive measures should also be addressed. Inspection 
may never be a routine task. If it happens in a different area of competence, the competent regional leader or commander conducts the briefing.

\section{Investigation Following the Use of Coercive Means}

After the use of coercive means, an investigation shall be conducted by the head of the body taking the measures. The investigation starts with the verbal report of the person using the coercive means. Afterwards, the inspector shall submit a written report within two days following the use of coercive means.

\section{Report Obligations of the Person Taking Measures}

A verbal report should only contain the most important information related to taking coercive measures. If the inspector was attacked, investigation of violence against an official shall be ordered. The oral report shall be made to the head of the body taking measures.

Main content elements of the verbal report:

- when, where, for what reason, against whom was it used and what coercive measures were taken;

- did personal injury happen, if yes, what treatment was the injured granted;

- other aspects regarded as important by the person reporting.

After an oral report, one shall prepare a written report at their service location. In this report, facts and information related to the use of coercive means must be described in detail. The written report shall be made by all who were present at the inspection for the sake of a posterior thorough commander's investigation. At a joint and combined inspection, the personnel are seconded from several organisations. In such cases, reports made at different service locations shall be sent by email to the person investigating, then in original, signed by the person reporting. This report on the use of coercive means shall detail the answers to the below main questions: where, when, against whom, for how long time, what kind of coercive measures were taken and for what reason.

Content elements of the written report:

- name(s) of the person(s) against whom measures were taken or coercive means used;

- concerning the use of coercive means or measures taken:

- location

- time

- duration

- the method of defiance against their use

- type

- short description of use

- the occurrence and description of the injury during the use of coercive means, in case of eventual medical treatment, the name of the ambulance officer or physician. If the injured was transported, the name of the health care institution;

- if notice was given to stop the unlawful behaviour, if not, what was its reason; 
G. SCHWEICKHARDT: Leadership Tasks Associated with the Use of Coercive Means...

- if preliminary notice was provided on the use of coercive means, if not, what was its reason;

- if property was damaged, its amount;

- what happened to the injured, any measure taken to treat them, if not, what was its reason;

- description of the means used for attack, if coercive means were used because of an attack;

- natural identification data and address of witnesses;

- a reference to all legislation sources allowing the use of coercive means.

\section{Commander's Investigation}

In the summary report, ascertainment on legitimacy and professionalism shall be made, referring to the relevant legislation sources. The legitimacy of the use of coercive means shall be adjudged based on Act CXXVIII of 2011 and according to Act CXX of 2012 on the activities of persons performing certain policing tasks, and on the amendment of certain acts ensuring actions against truancy. Under paragraph (1) of Section 24/A of Act CXXVIII of 2011: “A professional personnel of a professional disaster management body performing the authoritative inspection of the transportation of dangerous goods (hereinafter referred to as a member of the personnel) is authorized

a) to give verbal notice to the person caught in the act of offense or crime to cease the act, and to prevent them from continuing the act,

b) to detain a person caught in the act of crime until the arrival of the Police, but maximum up to two hours of duration.”

Based on legal connotations, a general authorisation seems to appear in relation to professional disaster management bodies. Therefore, it is also necessary to investigate the extent an inspector knows and is able to apply different penal laws. The limitation of the scope of responsibilities of professional disaster management bodies was omitted from the regulation.

An investigation should always be performed uniquely, adjusted to a particular situation. After using handcuffs, real-life as well as special and unique circumstances should also be assessed. Based on the written reports of the persons taking measures and those present, the person investigating, submits to their commander, within three days, through their professional superior their summary report containing their classification recommendation.

During the investigation, the commander, inter alia:

- investigates the report of the inspector and the data available; if needed, the commander interviews the inspectors who were present during the action and witnessed the use of coercive means;

- investigates all duty documents and registries computerised databases and applications that (may) contain information on the incident, and the relevant data shall be included in the report;

- publicly accessible imagery or voice recording(s) eventually made on the measures taken by the inspector; if possible, they should be collected, and the facts assessed based on the latter, recorded in the minutes. 
During the commander's investigation, inter alia, it is necessary to investigate the conditions for the use of coercive means. It not only means that the conditions for the use of coercive means shall be investigated, but also the existence of the conditions and the duration of detention. If the duration of detention was over two hours, the inspector has committed a criminal offense, and a criminal report shall be submitted. An inspector may commit certain other official criminal offenses during the use of coercive means, e.g. unlawful detention.

The same way, during an injury caused by the use of coercive means, if it had caused serious bodily injury, criminal procedure shall be launched.

The main content elements of the summary report:

- time and venue of the incident;

- name, rank and site of assignment of the person taking the measures;

- description of the incident:

- if the conduct of the person against whom measures were taken justified the use of coercive means

- if the use of coercive means was preceded by a verbal notice on the cessation of an unlawful act and a warning envisaging the use of a coercive means

- if the legal requirements of the use of coercive means prevailed: i.e. if it was necessary, if it was lawfully used, if its use was proportionate, if proper means in service were used for a justifiable duration

- if the use of coercive means had caused injury, who suffered what kind of injury

- if measured were taken for first aid or medical care by a physician, in case of hospitalisation, data concerning transportation and the hospital

- if the superior interviewed the affected persons or witnesses

- if the eventual contradictions were clarified

- if the superior has made a detailed report on the investigation

- if the initiation of additional procedures has become necessary, the necessary measures were taken or not.

Within 5 days following the commander's investigation, the report shall be submitted to the Deputy Director General for Authoritative Affairs.

The result of the commander's investigation may be that the use of coercive means was:

- Case 1: lawful and proper (professional);

- Case 2: lawful but improper (unprofessional);

- Case 3: unlawful and improper (unprofessional).

In Case 1, the use of coercive means fully met the legal requirements, and was performed according to technical regulations.

In Case 2, the measures were taken unprofessionally; at least, a disciplinary procedure shall be conducted. If the use of coercive means has caused a permanent injury or an injury lasting over 8 (eight) days, a criminal procedure shall be carried out already based on the suspicion of crime.

In Case 3, a criminal procedure shall be carried out already based on the suspicion of crime. 


\section{Complaint Investigation Following the Use of Coercive Means}

The investigation of complaints following the use of coercive means may be requested by the person whose basic rights were infringed or whose legitimate interests were affected. Complaint may be submitted to the head of the professional disaster management body taking coercive measures. The complaint shall be investigated asper the rules of public administration authoritative procedures, and a decision shall be made within 21 days following the receipt of the submission. Request shall be submitted within 8 (eight) days; in case the person affected becomes aware of the detriment of their rights post factum, within 3 months following the use of coercive means may a request be submitted.

\section{Summary}

The public road inspection of dangerous goods, in addition to special knowledge, sets further requirements for the inspecting personnel. In this respect, a new criterion has appeared concerning the use of coercive means also for persons commanding and controlling such personnel. By this, the law enforcement tasks of professional disaster management organisations have increased. Leaders and commanders should establish legal knowledge and leadership skills concerning the use of coercive means.

\section{References}

[1] PARÁDI J. szerk.: A magyar rendvédelem története. Budapest: Osiris Kiadó, 1996.

[2] Protocol I. Additional to the Geneva Conventions of $12^{\text {th }}$ August 1949 and on the Protection of Victims of International Armed Conflicts.

[3] Law Decree 10 of 1973 on the Protection against Fire and on the Fire Service.

[4] Act LXXIV of 1999 on the Direction of Protection against Disasters, on Its Organization and on the Protection against Major Accidents Involving Hazardous Materials.

[5] Act XXXVII of 1996 on the Civil Protection.

[6] Act CXXVIII of 2011 on Disaster Management and the Amendment of Certain Relevant Acts.

[7] NECEFOR B.: Kényszerítő eszközök alkalmazása a rendvédelemben. [Application of non-lethal weapons in law enforcement.] Degree thesis. Miskolc: Miskolci Egyetem, 2015.

[8] Decree of the Minister of the Interior 49/2011 (XII. 20.) on the Service Regulations of the Personnel of Professional Disaster Management Bodies and of Civil Protection Organizations. 